\title{
Blood Relations
}





\section{Blood Relations}

Menstruation and the Origins of Culture

\section{Chris Knight}

Yale University Press

New Haven and London 1991 


\section{Copyright (C) 1991 by Chris Knight}

All rights reserved. This book may not be reproduced, in whole or in part, in any form (beyond that copying permitted by Sections 107 and 108 of the US Copyright Law and except by reviewers for the public press) without written permission from the publishers.

Set in Garamond by Excel Typesetters Co., Hong Kong

Printed and bound in Great Britain

ISBN 978-0-300-04911-4

Library of Congress Catalog Number 90-71194 
To my children, Rosie, Olivia and Jude 
'The philosophers have only interpreted the world in different ways; the point is to change it.'

Karl Marx, Theses on Feuerbach: XI (1845) 